\title{
LEVERAGING THE PEACEBUILDING POTENTIAL OF CROSS-BORDER TRADER NETWORKS IN SUB-SAHARAN AFRICA
}

\author{
MARYAM ROKHIDEH
}

LEARNING FROM LOCAL

PEACEBUILDING APPROACHES

\section{${ }^{6}$ As actors embedded in licit and illicit networks at local and regional levels, cross-border traders have the potential to fuel conflict or mitigate it."}

\section{FAST FACTS}

$\rightarrow$ In seeking to protect their investments, cross-border traders have established hybrid security arrangements that have indirectly contributed to peacebuilding.

$\rightarrow$ Cross-border traders are at the intersection of many conflict drivers. Assessing their roles as potential spoilers of conflict or as peace actors is key to successful peacebuilding programming.

$\rightarrow$ Cross-border trader networks are a potential resource for accessing critical information and intelligence at various levels.

$\rightarrow$ Trainings should be provided to build the peacebuilding capacity of cross-border trader networks and associations.

\section{Context}

Cross-border trade plays a prominent role in economic, social, and political life in Sub-Saharan Africa, contributing significantly to development, poverty reduction, and job creation. Across the continent, cross-border trade accounts for 43 percent of the entire population's income. ${ }^{1}$ As actors embedded in licit and illicit networks at local and regional levels, cross-border traders have the potential to fuel conflict or mitigate it. They can act as spoilers, supporting armed groups and war economies, or as peace intermediaries, negotiating peace deals and bridging

1 Jean-Guy K. Afrika and Gerald Ajumbo, "Informal Cross Border Trade in Africa: Implications and Policy Recommendations," African Development Bank Africa Economic Brief 3, no. 10 (November 2012), https://www.sdgfund.org/informal-cross-border-trade-africaimplications-and-policy-recommendations; International Centre for Trade and Sustainable Development, "Supporting Small-Scale Cross-Border Traders Across Africa," Bridges Africa 7, no. 4 (2018), https://ictsd.iisd.org/bridges-news/bridges-africa/issue-archive/ supporting-small-scale-cross-border-traders-across-africa. 
conflict divides across communities. Given that most armed conflicts in Sub-Saharan Africa are shaped by cross-border dynamics, ${ }^{2}$ cross-border traders present an underexamined yet critical point of entry for analyzing and addressing conflicts and should be included in new and ongoing peacebuilding programming.

This policy note provides recommendations on how policymakers can leverage the untapped peacebuilding potential of cross-border traders and decrease their spoiling power. Specifically, cross-border trader groups can and should be engaged in four key ways:

- Cross-border traders and their networks can play a central role in meeting major security and governance needs, particularly in areas characterized by limited state capacity.

- They can indirectly contribute to peace and development outcomes by providing jobs and services to underserved groups such as women and unskilled youth who are targets of recruitment efforts by armed groups.

- As entities with long-standing inter-ethnic, inter-religious, and inter-generational ties, cross-border trader networks can contribute directly to communityled peacebuilding efforts by brokering trust between community groups and strengthening non-violent conflict management mechanisms.

- Finally, considering their close ties with patronage networks, natural resource flows, and local political economies, cross-border traders and their networks can serve as a critical early-warning source of information on armed group activities, conflict recurrence, and illicit funding streams.

\section{Relevance to policy and practice}

Recent policy initiatives underlining the importance of cross-border cooperation in mitigating conflict and violent extremism present an opportunity to incorporate cross-border traders in these efforts. USAID's West Africa Regional Development Cooperation Strategy and the African Union Convention on Cross Border Cooperation make community-led cross-border cooperation a key policy priority for enhancing security and regional integration in Africa. ${ }^{3}$ Among others, the United Nations Development Program (UNDP) African Borderlands Program, the Economic Community of West African States (ECOWAS) Regulatory Informal Trade Program, and the Common Market for Eastern and Southern Africa (COMESA) Great Lakes Trade Facilitation Project all note the significance of cross-border trade in sustaining local livelihoods, food security, and women's empowerment. ${ }^{4}$

2 Noel Twagiramungu, Allard Duursma, Mulugeta Gebrehiwot Berhe, and Alex de Waal, "Re-Describing Transnational Conflict in Africa," The Journal of Modern African Studies 57, no. 3 (2019): 377-91, https://doi.org/10.1017/S0022278X19000107.

3 See: "Regional Development Cooperation Strategy (2020-2025)," U.S. Agency for International Development, West Africa Regional, last updated June 1, 2021, https://www.usaid.gov/west-africa-regional/rdcs; "African Union Convention on Cross Border Cooperation (Niamey Convention)," African Union, June 27, 2014, https://au.int/sites/default/files/treaties/36416treaty-0044 - niamey convention african union convention on cross-border cooperation e.pdf.

4 See: "Africa Borderlands Centre," United Nations Development Programme, accessed June 13, 2021, https://www.africa. undp.org/content/rba/en/home/AfricaBorderlandsCentre.html; "ECOWAS Moves to Streamline Informal Trade in the 
These interventions, however, treat security and governance challenges separately from issues related to cross-border trade, and thus identify separate and uncoordinated solutions. Despite their contributions to security governance and peace and development outcomes, cross-border traders have yet to be incorporated into local peacebuilding approaches.

Even if cross-border traders are not directly stepping into peacebuilding roles or are not necessarily driven by peace objectives, they impact the political economy of conflict-affected areas and should be included in new and ongoing programming. Cross-border trade can indirectly contribute to peacebuilding by reducing unemployment, a factor leading to violent conflict and recruitment into armed groups. ${ }^{5}$ For example, cross-border trade between Uganda and South Sudan has contributed to stability and socio-economic recovery in the region, providing a key source of employment for unskilled youth, who have been targeted for recruitment into armed groups. ${ }^{6}$ Efforts need to be made to ensure that participation in cross-border trade and other income-generating activities is inclusive and all groups can reap the benefits and opportunities.

In seeking to protect their investments, cross-border traders have established hybrid security arrangements that have indirectly contributed to peacebuilding. For example, in the contested Abyei region of the Sudan-South Sudan borderland two conflicting groups, the Ngok and the Misseriya, negotiated peace deals and security guarantees that provided protection and policing in the region. ${ }^{7}$ The Ngok and the Misseriya traders set up a thriving cross-border market that became a meeting place for the local peace council. Despite sabotage attempts by the Government of Sudan, security guarantees established by the Ngok and the Misseriya traders created a safe haven in a contentious area where the passage of peoples and goods had been previously blocked. Reportedly, the re-opening of trade relations between Sudan and South Sudanese also had a positive impact on militia group activities, as they benefitted from new income streams they resorted to less looting and criminality. ${ }^{8}$ The desire to facilitate trade gave Sudanese and South Sudanese cross-border traders the impetus to re-build severed relations and establish trust and confidence based on mutual interdependence.

In a similar case, Nande traders in the Democratic Republic of Congo negotiated hybrid security arrangements with state and non-state armed groups, including the Rwandan and Ugandan-backed Rassemblement Congolais pour la Démocratie - Mouvement de Libération (RCD-ML). ${ }^{9}$ In their aims to generate profit and protect their investments, the Nande traders' security arrangements with armed groups not only ensured protection and security provisions for themselves but also

Region," AllAfrica, April 12, 2012, https://allafrica.com/stories/201204121119.html; "Great Lakes Trade Facilitation Project," COMESA, World Bank, accessed June 13, 2021, https://gltfp.comesa.int/.

5 USAID, Conflict Assessment Framework Version 2.0. (Washington, D.C.: United States Agency for International Development, 2012), https://pdf.usaid.gov/pdf docs/pnady739.pdf.

6 Graham Carrington, Cross-border Trade: Fueling Conflict or Building Peace?: An exploration of cross-border trade between Sudan and Uganda and the implications for peacebuilding (Conciliation Resources, 2009), https://rc-services-assets.s3.euwest-1.amazonaws.com/s3fs-public/Cross borderTrade 200909 ENG.pdf.

7 Øystein H. Rolandsen, "Trade, Peace-building and Hybrid Governance in the Sudan-South Sudan Borderlands," Conflict, Security \& Development 19, no. 1 (2019): 79-97, https://doi.org/10.1080/14678802.2019.1561628.

8 Rolandsen, "Trade, Peace-building and Hybrid Governance."

9 Timothy Raeymaekers, Violent Capitalism and Hybrid Identity in the Eastern Congo: Power to the Margins (New York, NY: Cambridge University Press, 2014). 
for the wider population. ${ }^{10}$ In the process of safeguarding their own commercial interests during armed conflict, Nande cross-border traders generated a new form of hybrid governance and political order in the region that fulfilled state-like functions like establishing judicial systems, constructing schools and public infrastructure, and providing important goods and services. ${ }^{11}$ As a result, the northeastern sub-region of eastern DR Congo was able to trade, develop, and progress at higher level than in other conflict-affected areas of the country. ${ }^{12}$ These examples demonstrate the role cross-border traders play in the regulation of violence, politics, and governance locally and regionally, and that they are a critical yet untapped resource for community-led and owned peacebuilding.

A key point to consider is that even if cross-border traders are not directly stepping into peacebuilding roles or are not necessarily driven by peace objectives, they nonetheless impact the political economy of conflict-affected areas and should be included as key actors in new and ongoing programming. Cross-border trade can indirectly contribute to peacebuilding by reducing unemployment, which is a factor leading to violent conflict and recruitment into armed groups. ${ }^{13}$ For example, cross-border trade between Uganda and South Sudan has contributed to stability and socio-economic recovery in the region, providing a key source of employment for unskilled youth, who have been targeted for recruitment into armed groups. ${ }^{14}$ It is important to note that efforts need to be made to ensure that participation in cross-border trade and other incomegenerating activities is inclusive and all groups can reap the benefits and opportunities.

In areas affected by intercommunal tensions and limited state presence, such as in the SahelSahara or the Democratic Republic of Congo, strengthening relations and interrelations between communities is a key factor in resolving conflicts and preventing radicalization. ${ }^{15}$ Research on violent extremism in Sub-Saharan Africa finds that bridge-building ties such as those developed by cross-border trader associations contribute to communities' ability to counter threats and prevent violence. ${ }^{16}$ While bonding ties-connections within similar ethnic, religious, or generational groups, such as among members of al-Shabaab or the New People's Army in the Philippines (CPPNPA) - are associated with increased levels of conflict and violent extremism, bridging ties - those developed between different groups, such as among Christian-Muslim business associations in Kenya-correlate with lower levels of communal and sectarian violence. ${ }^{17}$ Cross-border trade

10 Patience Kabamba, Business of Civil War: New Forms of Life in the Debris of the Democratic Republic of Congo (Dakar, Senegal: CODESRIA, 2013).

11 Filip Reyntjens, "Regulation, Taxation and Violence: The State, Quasi-State Governance and Cross-Border Dynamics in the Great Lakes Region," Review of African Political Economy 41, no. 142 (2014): 530-44, https://doi.org/10.1080/03056244.20 14.928612

12 Laura Seay, "Why One City in Congo is Astonishingly Stable and Prosperous," Washington Post, July 31, 2015, https://www. washingtonpost.com/news/monkey-cage/wp/2015/07/31/why-one-city-in-congo-is-astonishingly-stable-and-prosperous/.

13 USAID, Conflict Assessment Framework Version 2.0.

14 Carrington, Cross-border Trade: Fueling Conflict or Building Peace?

15 Rahmane Idrissa and Bethany McGann, Mistrust and Imbalance: The Collapse of Intercommunal Relations and the Rise of Armed Community Mobilization on the Niger-Mali Border (Washington, D.C.: RESOLVE Network, 2021), https://doi. org/10.37805/cbags2021.2.

16 Lauren Van Metre, Community Resilience to Violent Extremism in Kenya (Washington, D.C.: U.S. Institute of Peace, 2016), https://www.usip.org/publications/2016/10/community-resilience-violent-extremism-kenya.

17 Ami C. Carpenter, Community Resilience to Sectarian Violence in Baghdad (New York: Springer, 2014); Van Metre, Community Resilience to Violent Extremism in Kenya.

ReSOlVe Policy Note \Leveraging the Peacebuilding Potential of Cross-border Trader Networks | 4 
associations created by women in the Great Lakes region have built inter-ethnic, inter-religious, and inter-group cooperation over generations and helped to bridge historically contentious relations between DR Congo, Rwanda, Uganda, and Burundi. Participation in such associations by marginalized groups like women and former combatants can contribute to fostering peace and social cohesion, as these underserved groups can directly or indirectly mitigate against community animosities. ${ }^{18}$

Having networks that often overlap with covert networks, involving state, non-state, and criminal actors, cross-border traders wield significant influence in controlling vital resources, modes of exchange, and information and intelligence across borders. ${ }^{19}$ The illicit trafficking of small arms, natural resources, and wildlife are often embedded and entangled in the same routes as other forms of legitimate trade. ${ }^{20}$ Trade in natural resources like gold and cassiterite, for example, pass through the hands of cross-border traders through illicit and licit channels in DR Congo and Uganda, and help fuel armed groups operating in these areas. ${ }^{21}$ Since traders play a crucial role as facilitators linking local and international markets, they are a key resource for identifying illicit activities and resource flows.

For example, state and non-state armed groups operating in the border regions of DR Congo, Uganda, and Rwanda, including the recently U.S. designated terrorist organization, the Allied Democratic Forces (ADF) have a long history of establishing deals with cross-border traders and local businesspeople. ${ }^{22}$ Quintessential to the resilience of armed groups in the region is their successful integration into the cross-border economy both in terms of taxing schemes and the illicit trafficking of natural resources such as gold, timber, and most recently cocoa across borders. ${ }^{23}$ New research finds that there is a strong correlation between the illicit trade of cocoa and spikes in violence by ADF and other armed groups. ${ }^{24}$ Tracking the flows of lucrative commodities through cross-border trade networks can provide critical information on the funding sources, alliances, and organizational dynamics of armed groups.

18 USAID, A Guide to Economic Growth in Post-Conflict Countries (Washington, D.C.: United States Agency for International Development, 2009), https://pdf.usaid.gov/pdf docs/Pnado408.pdf.

19 Alan Martin and Helene Helbig de Balzac, "The West African El Dorado: Mapping the Illicit Trade of Gold in Côte d'Ivoire, Mali and Burkina Faso Illicit trade in natural resources in Africa," Africa Portal, November 1, 2016, https://www.africaportal.org/ publications/west-african-el-dorado-mapping-illicit-trade-gold-côte-divoire-mali-and-burkina-faso/.

20 Nicolas Florquin, Linking P/CVE and Illicit Arms Flows in Africa (Washington, D.C.: RESOLVE Network, 2019), https://doi. org/10.37805/pn2019.1.ssa.

21 Reyntjens, "Regulation, Taxation and Violence."

22 Patrycja Stys, Judith Verweijen, Papy Muzuri, Samuel Muhindo, Christoph Vogel, and Johan H Koskinen, "Brokering Between (not so) Overt and (not so) Covert Networks in Conflict Zones," Global Crime 21, no. 1 (2020): 74-110, https://doi.org/10.10 $\underline{80 / 17440572.2019 .1596806 .}$

23 Kristof Titeca and Daniel Fahey, "The Many Faces of a Rebel Group: The Allied Democratic Forces in the Democratic Republic of Congo," International Affairs 92, no. 5 (2016): 1189-1206, https://doi.org/10.1111/1468-2346.12703.

24 Author interview with independent researcher and journalist in DR Congo; Forthcoming UN Group of Experts Report on DR Congo. 


\section{Recommendations}

\section{Invest in researching the constructive and destructive roles of cross-border traders in conflicts}

Cross-border traders are at the intersection of many conflict drivers. Assessing their roles as potential spoilers of conflict or as peace actors is key to successful peacebuilding programming. Policy initiatives should carry out context-specific assessments of the local private sector and cross-border traders. Community Asset Mapping ${ }^{25}$ can identify the existing capacities and relations between community members and traders, including key areas where interaction and cooperation between different community groups are facilitated. This kind of mapping exercise provides information on the different roles traders fulfill in communities, which can inform new and ongoing programming.

Social Network Analysis (SNA), a practical tool used to identify and map social relationships, can be conducted to provide critical information on the social structure, composition, influence, and organization of trader networks. Specific attention needs to be made to trader groups' ethnic and religious ties as this can provide insights on how to leverage existing bridge-building ties in order to facilitate social cohesion, cooperation, and mutual interdependence. SNA can help determine the level of embeddedness of traders in criminal networks and provide crucial insights on key actors, funding streams, and channels of information exchange between cross-border traders and violent actors. ${ }^{26}$ The relationships between cross-border traders and armed groups are at times mutually constitutive. Mapping cross-border trader networks and their business ties can reveal the financial sources and backers of armed groups and criminal networks. Lessons can be learned for instance from Social Network Analysis conducted by the Organization for Economic Cooperation and Development (OECD) on trader networks and violent extremist organizations in North and West Africa. ${ }^{27}$

\section{Leverage the information and intelligence networks of cross-bor- der traders}

Cross-border trader networks are a potential resource for accessing critical information and intelligence at various levels. In many borderland areas such as the Southern Africa Development Community (SADC) region, reliable information and statistics are hard to come by and need to be supported by alternatives embedded in these networks. Cross-border traders often have the most up-to-date and accurate information on conflict drivers and community dynamics and as such

25 Community Asset Mapping is a participatory tool that can provide information on a community's resources and existing strengths to support or facilitate community-owned solutions.

Olivier J. Walther and William F.S. Miles (eds.), African Border Disorders: Addressing Transnational Extremist Organizations (New York: Routledge, 2018).

27 OECD Sahel and West Africa Club, Conflict Networks in North and West Africa (Paris, France: OECD Publishing, West African Studies, 2021), https://doi.org/10.1787/896e3eca-en; Olivier Walther and Christian Leuprecht, "Mapping and Deterring Violent Extremist Networks in North-West Africa," Department of Border Region Studies Working Paper No. 04/15 (2015), https://doi.org/10.2139/ssrn.2593020. 
should be utilized as a key resource. In the borderlands of DR Congo, Uganda, and South Sudan, for instance, state and non-state armed groups depend on cross-border traders for intelligence, revenue generation, logistics, recruitment, and political communication. ${ }^{28}$ USAID's West Africa Peace and Governance program could also leverage and strengthen cross-border trader networks as a resource for information, intelligence sharing, and early warning as part of its promotion of conflict early warning and response. ${ }^{29}$ Tracing flows in border movements and exchanges through cross-border traders can reveal crucial insights into smuggling patterns and criminal activities. Policy initiatives should thus make concerted efforts to include cross-border traders in border security mechanisms such as the Multinational Joint Task Force that patrols border security between Benin, Cameroon, Chad, Niger, and Nigeria.

\section{Strengthen the peacebuilding potential of existing cross-border trader networks and associations}

Given the power of bridge-building networks in preventing and mitigating conflicts, cross-border trader networks offer a critical point of entry for community-led peacebuilding. Policymakers could facilitate inclusive trade policies that contribute to building trust and mutual interdependencies between communities, providing incentives for cross-border cooperation and collective action. Lessons can be learned, for example, from peacebuilding initiatives by women cross-border trader associations in the Great Lakes region that established a Memorandum of Understanding to resolve cross-border disputes between DR Congo and Rwanda. ${ }^{30}$ Other examples include the Market Peace Committees in Bahr el-Ghazal and the sub-regional trader peace councils in Sudan and South Sudan. ${ }^{31}$

Policy initiatives can support and strengthen the peacebuilding capacities of cross-border trader associations by providing trainings and platforms for dialogue and conflict resolution. A prime example is the cross-border trader forums developed by COMESA, International Alert, and the author that brought together regional partners, border officials, and traders from different socioeconomic, religious, and generational backgrounds to improve relations and resolve tensions. ${ }^{32}$ Capacity-building programs must invite and include wide segments of the population to these forums in order to listen to and address the needs of all actors and maximize the benefits of cross-border trade.

28 Kristof Titeca, "Tycoons and Contraband: Informal Cross-Border Trade in West Nile, North-Western Uganda," Journal of Eastern African Studies 6, no. 1 (2012): 47-63, https://doi.org/10.1080/17531055.2012.664703; Stys et al., "Brokering Between (not so) Overt and (not so) Covert Networks in Conflict Zones."

29 "Regional Peace and Governance," U.S. Agency for International Development, West Africa Regional, last updated June 1, 2021, https://www.usaid.gov/west-africa-regional/democracy-human-rights-governance.

30 International Alert, "New trade agreement to help foster development and peace in Rwanda and DRC," October 20, 2016, https://www.international-alert.org/news/new-trade-agreement-help-foster-development-and-peace-rwanda-and-drc.

31 Evan Papp, "An island of peaceful coexistence along a river of turbulence," Devex, September 1, 2015, https://www.devex. com/news/an-island-of-peaceful-coexistence-along-a-river-of-turbulence-86809.

32 Maryam Rokhideh, "Improving Trade Relations between DR Congo and Rwanda," Narrative report, U.S. Embassy Kigali in partnership with University of Tourism Technology and Business Studies, March 2019. 


\section{Incorporate peacebuilding components in current cross-border initiatives}

Current initiatives-e.g. UNDP's African Borderlands Center, the ECOWAS Informal Trade Program, COMESA Cross-border Initiative, UN Capital Development Fund (UNCDF) and the West African Economic and Monetary Union (UEMOA) Cross-border Initiative ${ }^{33}$-all support cross-border trade in some way but do not include peacebuilding components. By adding a peacebuilding lens to these initiatives, policymakers can identify context-specific conditions that are favorable for local peacebuilding and cooperation. For example, a recent study finds that regional economic organizations in West Africa facilitate governance networks that elicit greater cross-border cooperation and combat transnational crime. ${ }^{34}$ Cross-border traders should be included in these initiatives in order to foster greater coordination in the areas of peace and security.

Furthermore, linkages could be strengthened between local trader associations and regional organizations, e.g. the East African Community (EAC), Intergovernmental Authority on Development (IGAD), SADC, and ECOWAS. Under ECOWAS, for example, each sub-region has a sectoral organization responsible for promoting cross-border interaction: the Senegal River Basin Development Organization (OMVS), Integrated Development Authority of the Liptako-Gourma Region (ALG), and the Lake Chad Basin Commission (LCBC). By setting up a forum and collaborating with these committees, governments can leverage relationships between cross-border trade coalitions and state and non-state actors, including smugglers, illicit actors, security providers, and border officials. Trainings should be provided to build the peacebuilding capacity of cross-border trader networks and associations.

33 See: "Africa Borderlands Centre," United Nations Development Programme, https://www.africa.undp.org/content/rba/en/ home/AfricaBorderlandsCentre.html; ECOWAS Informal Trade Program, accessed June 13, 2021, http://www.eco-icbt.org/; "Great Lakes Trade Facilitation Project," COMESA, World Bank, accessed June 13, 2021, https://gltfp.comesa.int; European Centre for Development Policy Management, "Political Economy Dynamics in Regional Organizations in Africa," 2017, https:// ecdpm.org/wp-content/uploads/ECOWAS-Trade-Policy-Brief-PEDRO-Political-Economy-Dynamics-Regional-OrganisationsAfrica-ECDPM-2017.

34 OECD Sahel and West Africa Club, Cross-border Co-operation and Policy Networks in West Africa (Paris, France: OECD Publishing, West African Studies, 2017), https://doi.org/10.1787/9789264265875-en. 


\section{Suggested Further Reading}

\section{On Cross-border Trade, War Economies, and Conflicts}

Kabamba, Patience. Business of Civil War: New Forms of Life in the Debris of the Democratic Republic of Congo. Dakar, Senegal: CODESRIA, 2013.

Raeymaekers, Timothy. Violent Capitalism and Hybrid Identity in the Eastern Congo: Power to the Margins. New York, NY: Cambridge University Press, 2014.

Titeca, Kristof. "Tycoons and Contraband: Informal Cross-Border Trade in West Nile, North-Western Uganda." Journal of Eastern African Studies 6, no. 1 (2012): 47-63. https://doi.org/10.1080/17531055.2012.664703.

Walther, Olivier J., and William F.S. Miles (eds.). African Border Disorders: Addressing Transnational Extremist Organizations. New York: Routledge, 2018.

\section{On the Peacebuilding Potential of Cross-Border Trade}

Berdal, Mats, and Nader Mousavizadeh. "Investing for Peace: The Private Sector and the Challenges of Peacebuilding." Survival 52 , no. 2 (2010): 37-58. https://doi.org/10.1080/00396331003764595.

International Alert. "Making trade work for peace in the Great Lakes." April 4, 2016. https://www.international-alert.org/news/ making-trade-work-for-peace-in-the-great-lakes.

Ramsbotham, Alexander, and I. William Zartman. Paix Sans Frontières: Building Peace across Borders. Accord: An International Review of Peace Initiatives, Issue 22. Conciliation Resources, January 2011. https://rc-services-assets.s3.eu-west-1.amazonaws.com/s3fs-public/Paix sans frontieres building peace across borders Accord Issue 22.pdf.

Rolandsen, Øystein H. "Trade, Peace-building and Hybrid Governance in the Sudan-South Sudan Borderlands." Conflict, Security \& Development 19, no. 1 (2019): 79-97. https://doi.org/10.1080/14678802.2019.1561628.

OECD Sahel and West Africa Club. Cross-border Co-operation and Policy Networks in West Africa. Paris, France: OECD Publishing, West African Studies, 2017. https://doi.org/10.1787/9789264265875-en.

\section{On Social Networks, Bridging Ties, and Armed Groups}

Carpenter, Ami C. Community Resilience to Sectarian Violence in Baghdad. New York: Springer, 2014.

Stys, Patrycja, Judith Verweijen, Papy Muzuri, Samuel Muhindo, Christoph Vogel, and Johan H Koskinen. "Brokering Between (not so) Overt and (not so) Covert Networks in Conflict Zones." Global Crime 21, no. 1 (2020): 74-110. https://doi.org/10.1080/1 $\underline{7440572.2019 .1596806 .}$

Van Metre, Lauren. Community Resilience to Violent Extremism in Kenya. Washington, D.C.: U.S. Institute of Peace, 2016. https:// www.usip.org/publications/2016/10/community-resilience-violent-extremism-kenya.

Walther, Olivier, and Christian Leuprecht. "Mapping and Deterring Violent Extremist Networks in North-West Africa." Department of Border Region Studies Working Paper No. 04/15 (2015). https://doi.org/10.2139/ssrn.2593020. 


\section{Bibliography}

"ECOWAS Moves to Streamline Informal Trade in the Region." AllAfrica, April 12, 2012. https://allafrica.com/stories/201204121119. html.

African Union. "African Union Convention on Cross Border Cooperation (Niamey Convention)." June 27, 2014. https://au.int/ sites/default/files/treaties/36416-treaty-0044 - niamey convention african union convention on cross-border cooperation e.pdf. https://au.int/en/treaties/african-union-convention-cross-border-cooperation-niamey-convention.

Afrika, Jean-Guy K., and Gerald Ajumbo. "Informal Cross Border Trade in Africa: Implications and Policy Recommendations." African Development Bank Africa Economic Brief 3, no. 10 (November 2012). https://www.sdgfund.org/ informal-cross-border-trade-africa-implications-and-policy-recommendations.

Carpenter, Ami C. Community Resilience to Sectarian Violence in Baghdad. New York: Springer, 2014.

Carrington, Graham. Cross-border Trade: Fueling Conflict or Building Peace?: An exploration of cross-border trade between Sudan and Uganda and the implications for peacebuilding. Conciliation Resources, 2009. https://rc-services-assets.s3.eu-west-1. amazonaws.com/s3fs-public/Cross borderTrade 200909 ENG.pdf.

COMESA, World Bank. "Great Lakes Trade Facilitation Project." Accessed June 13, 2021. https://gltfp.comesa.int/.

ECOWAS Informal Trade Program. Accessed June 13, 2021. http://www.eco-icbt.org/.

European Centre for Development Policy Management. "Political Economy Dynamics in Regional Organizations in Africa." 2017. https://ecdpm.org/wp-content/uploads/ECOWAS-Trade-Policy-Brief-PEDRO-Political-Economy-Dynamics-Regional-Organisations-Africa-ECDPM-2017.

Florquin, Nicolas. Linking P/CVE and Illicit Arms Flows in Africa. Washington, D.C.: RESOLVE Network, 2019. https://doi. org/10.37805/pn2019.1.ssa.

Idrissa, Rahmane, and Bethany McGann. Mistrust and Imbalance: The Collapse of Intercommunal Relations and the Rise of Armed Community Mobilization on the Niger-Mali Border. Washington, D.C.: RESOLVE Network, 2021. https://doi.org/10.37805/ cbags2021.2.

International Alert. "New trade agreement to help foster development and peace in Rwanda and DRC." October 20, 2016. https:// www.international-alert.org/news/new-trade-agreement-help-foster-development-and-peace-rwanda-and-drc.

International Centre for Trade and Sustainable Development. "Supporting Small-Scale Cross-Border Traders Across Africa." Bridges Africa vol. 77, issue no. 4 (2018). https://ictsd.iisd.org/bridges-news/bridges-africa/issue-archive/ supporting-small-scale-cross-border-traders-across-africa.

Kabamba, Patience. Business of Civil War: New Forms of Life in the Debris of the Democratic Republic of Congo. Dakar, Senegal: CODESRIA, 2013.

Martin, Alan, and Helene Helbig de Balzac. "The West African El Dorado: Mapping the Illicit Trade of Gold in Côte d'Ivoire, Mali and Burkina Faso Illicit trade in natural resources in Africa." Africa Portal, November 1, 2016. https://www.africaportal.org/ publications/west-african-el-dorado-mapping-illicit-trade-gold-côte-divoire-mali-and-burkina-fasol.

OECD Sahel and West Africa Club. Cross-border Co-operation and Policy Networks in West Africa. Paris, France: OECD Publishing, West African Studies, 2017. https://doi.org/10.1787/9789264265875-en.

OECD Sahel and West Africa Club. Conflict Networks in North and West Africa. Paris, France: OECD Publishing, West African Studies, 2021. https://doi.org/10.1787/896e3eca-en. 
Papp, Evan. "An island of peaceful coexistence along a river of turbulence." Devex, September 1, 2015. https://www.devex.com/ news/an-island-of-peaceful-coexistence-along-a-river-of-turbulence-86809.

Raeymaekers, Timothy. Violent Capitalism and Hybrid Identity in the Eastern Congo: Power to the Margins. New York, NY: Cambridge University Press, 2014.

Reyntjens, Filip. "Regulation, Taxation and Violence: The State, Quasi-State Governance and Cross-Border Dynamics in the Great Lakes Region." Review of African Political Economy 41, no. 142 (2014): 530-44. https://doi.org/10.1080/03056244.2014.92 $\underline{8612 .}$

Rokhideh, Maryam. "Improving Trade Relations between DR Congo and Rwanda." Narrative report, U.S. Embassy Kigali in partnership with University of Tourism Technology and Business Studies, March 2019.

Rolandsen, Øystein H. "Trade, Peace-building and Hybrid Governance in the Sudan-South Sudan Borderlands." Conflict, Security \& Development 19, no. 1 (2019): 79-97. https://doi.org/10.1080/14678802.2019.1561628.

Seay, Laura. "Why One City in Congo is Astonishingly Stable and Prosperous." Washington Post, July 31, 2015. https://www.washingtonpost.com/news/monkey-cage/wp/2015/07/31/why-one-city-in-congo-is-astonishingly-stable-and-prosperous/.

Stys, Patrycja, Judith Verweijen, Papy Muzuri, Samuel Muhindo, Christoph Vogel, and Johan H Koskinen. "Brokering Between (not so) Overt and (not so) Covert Networks in Conflict Zones." Global Crime 21, no. 1 (2020): 74-110. https://doi.org/10.1080/1 7440572.2019.1596806.

Titeca, Kristof. "Tycoons and Contraband: Informal Cross-Border Trade in West Nile, North-Western Uganda." Journal of Eastern African Studies 6, no. 1 (2012): 47-63. https://doi.org/10.1080/17531055.2012.664703.

Titeca, Kristof, and Daniel Fahey. "The Many Faces of a Rebel Group: The Allied Democratic Forces in the Democratic Republic of Congo." International Affairs 92, no. 5 (2016): 1189-1206. https://doi.org/10.1111/1468-2346.12703.

Twagiramungu, Noel, Allard Duursma, Mulugeta Gebrehiwot Berhe, and Alex de Waal. "Re-Describing Transnational Conflict in Africa." The Journal of Modern African Studies 57, no. 3 (2019): 377-91. https://doi.org/10.1017/S0022278X19000107.

United Nations Development Programme. "Africa Borderlands Centre." Accessed June 13, 2021. See https://www.africa.undp. org/content/rba/en/home/AfricaBorderlandsCentre.html.

USAID. A Guide to Economic Growth in Post-Conflict Countries. Washington, D.C.: United States Agency for International Development, 2009. https://pdf.usaid.gov/pdf docs/Pnado408.pdf.

USAID. Conflict Assessment Framework Version 2.0. Washington, D.C.: United States Agency for International Development, 2012. https://pdf.usaid.gov/pdf docs/pnady739.pdf.

USAID. "Regional Peace and Governance." U.S. Agency for International Development, West Africa Regional, last updated June 1, 2021. https://www.usaid.gov/west-africa-regional/democracy-human-rights-governance.

USAID. "Regional Development Cooperation Strategy (2020-2025)." U.S. Agency for International Development, West Africa Regional, last updated June 1, 2021. https://www.usaid.gov/west-africa-regional/rdcs.

Van Metre, Lauren. Community Resilience to Violent Extremism in Kenya. Washington, D.C.: U.S. Institute of Peace, 2016. https:// www.usip.org/publications/2016/10/community-resilience-violent-extremism-kenya.

Walther, Olivier J., and William F.S. Miles (eds.). African Border Disorders: Addressing Transnational Extremist Organizations. New York: Routledge, 2018.

Walther, Olivier, and Christian Leuprecht. "Mapping and Deterring Violent Extremist Networks in North-West Africa." Department of Border Region Studies Working Paper No. 04/15 (2015). https://doi.org/10.2139/ssrn.2593020. 


\section{About the Note}

Author: Maryam Rokhideh

Maryam Rokhideh is a doctoral researcher at the Kroc Institute of International Peace Studies at the University of Notre Dame, a fellow with the Woodrow Wilson National Foundation, and a visiting research fellow at the University of Vienna. Maryam has extensive experience conducting research and managing development projects in fragile and conflict-affected settings, including in the Democratic Republic of Congo, Uganda, Burundi, Rwanda, and Colombia. She regularly consults government and UN agencies, including USAID, WHO, UN Women, and IFAD on the effects of conflicts and emerging threats on livelihoods, gender, and health. Her research has been supported by the U.S. Department of State, National Science Foundation (NSF), Woodrow Wilson Foundation, Fulbright, and USAID.

The views expressed in this publication are those of the authors. They do not necessarily reflect the views of the RESOLVE Network, the U.S. Institute of Peace, or any entity of the U.S. government.

RESOLVE NETWORK

better research.informed practice.improved policy on violent extremism.

www.resolvenet.org

y 9 in.

United STATES

InSTITUTE OF Peace

Making Peace Possible 